\title{
Vegetative development of Turiaçu pineapple under two ecological conditions in Maranhão, Brazil
}

\author{
Letícia Moura Ramos ${ }^{1}$, Fabrício de Oliveira Reis ${ }^{2}$, \\ José Ribamar Gusmão Araujo ${ }^{3,}$ Isaias dos Santos Reis ${ }^{4}$, Rawlisson Silva Gonçalves ${ }^{5}$, \\ Augusto César Vieira Neves Junior ${ }^{6}$
}

\begin{abstract}
Pineapple plants of the cultivar Turiaçu are important for the fruit production sector in the state of Maranhão (MA), Brazil, because of their fruit quality and local social and economic value. The objective of the present work was to evaluate characteristics of pineapple plants of the cultivar Turiaçu at vegetative and propagative stages in two places, using two fertilization sources. The study was conducted in the municipalities of Turiaçu and São Luís, MA, using mineral and organic fertilizations. The plants were evaluated for number of leaves and leaf dry weight; stem diameter, length, and dry weight; width, length, and fresh and dry weights of the D leaf; and number of suckers (plantlets). Plants grown in Turiaçu under mineral fertilization had higher number of leaves (up to $162.5 \%$ higher) and higher number of suckers (up to $233.3 \%$ higher) than those grown in São Luís under organic fertilization. The results of the study indicate that the more favorable climate conditions in the municipality of Turiaçu were decisive for the success of the cultivar, and the organic fertilizer used was not adequate
\end{abstract}

Index terms: Ananas comosus var. comosus (L.) Merril; ecophysiology; propagation.

\section{Desenvolvimento vegetativo do abacaxi Turiaçu sob duas condições ecológicas no Maranhão, Brasil}

Corresponding author: gusmaoaraujo50@gmail.com

Received: March 30, 2019 Accepted: September 14, 2020

Copyright: All the contents of this journal, except where otherwise noted, is licensed under a Creative Commons Attribution License.
Resumo - A cultura do abacaxi da cultivar Turiaçu é importante para o setor frutícola do Estado do Maranhão (MA), Brasil, devido à qualidade dos frutos e pelo valor social e econômico local. O objetivo do presente trabalho foi avaliar características de plantas de abacaxizeiro da cultivar Turiaçu nos estádios vegetativo e propagativo, em dois locais, utilizando duas fontes de fertilização. O estudo foi realizado nos municípios de Turiaçu-MA e São Luís-MA, com o uso da adubação mineral e orgânica. As plantas foram avaliadas quanto ao número de folhas e à massa seca das folhas; diâmetro do caule, comprimento e massa seca; largura, comprimento e massa fresca e seca da folha D; e número de rebentos (mudas). As plantas cultivadas em Turiaçu, com adubação mineral, apresentaram maior número de folhas (até 162,5\% maior) e de número de mudas (até 233,3\% maior) do que as cultivadas em São Luís sob adubação orgânica. Os resultados do estudo indicam que as condições climáticas mais favoráveis do município de Turiaçu foram decisivas para o sucesso da cultivar, e a adubação orgânica utilizada não foi adequada.

Termos para indexação: Ananas comosus var. comosus (L.) Merril; ecofisiologia; propagação.

${ }^{1}$ Doctoral student in Agroecology, Maranhão State University - UEMA, São Luís-MA, Brazil, e-mail: letticiaramosagro77@gmail.com ${ }^{\text {(ORCID: }}$ 0000-0001-6529-1599)

${ }^{2}$ Agronomist, Professor at the Department of Biology, Maranhão State University - UEMA, São Luís-MA, Brazil, E-mail: fareoli@gmail.com (ORCID: 0000-0002-1781-3695)

${ }^{3}$ Agronomist, Professor at the Department of Plant Production Maranhão State University - UEMA, São Luís-MA, Brazil, E-mail:gusmaoaraujo50@ gmail.com (ORCID: 0000-0002-1430-9717)

${ }^{4}$ Doctoral student in Agronomy, Faculty of Agricultural and Veterinary Sciences - UNESP, Jaboticabal-SP, Brazil, E-mail: santos.isaias78@ gmail.com ${ }^{\text {(ORCID: }}$ 0000-0002-6381-6053)

${ }^{5}$ Agronomist, Maranhão State University - UEMA, São Luís-MA, Brazil, E-mail: rawlissongoncalvess@gmail.com (ORCID: 0000-0001-9627-939X) ${ }^{6}$ Agronomist, Researcher (PNPD/CAPES), Maranhão State University - UEMA, São Luís-MA, Brazil, E-mail: gutocesar@hotmail.com ${ }^{\text {(ORCID: }}$ 0000-0002-1438-5859) 
Pineapple production in Brazilian producing regions is usually carried out using the cultivar Perola. Plants of this cultivar are rustic and productive and can be grown in warm regions throughout the year, and their fruits are well accepted by the Brazilian consumer and have pronounced acidity. However, the cultivar Turiaçu is an option of sweeter and more commercially attractive fruits (KUAN et al., 2018; REINHARDT et al., 2002; REIS et al., 2019).

The cultivar Turiaçu originated from the municipality of Turiaçu, Maranhão (MA), Brazil, and its fruits are appreciated by consumers from Maranhão and neighboring states, and recently have reached the state of Amazonas. The cultivar Turiaçu have such importance that the Maranhão State decreed the creation of the
State Production and Establishment System (SEPAB) in 2015, which is responsible for the Turiaçu pineapple production chain (MARANHÃO, 2015). Despite this importance, information on the vegetative development and propagative characteristics of Turiaçu pineapple plants grown outside their place of origin are scarce. In this context, the objective of the present work was to evaluate characteristics of pineapple plants of the cultivar Turiaçu at vegetative and propagative stages in two places, using two fertilization sources.

The study was conducted in the municipalities of Turiaçu, MA $\left(01^{\circ} 38^{\prime} 58.6^{\prime} \mathrm{S}, 45^{\circ} 29^{\prime} 25.9^{\prime}\right.$ 'W) and

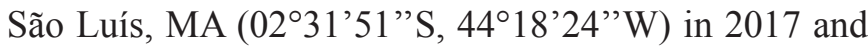
2018. Meteorological data in both municipalities during the experiment are shown in Figure 1 (INMET, 2019). No irrigation was used for the plants in the experiments.

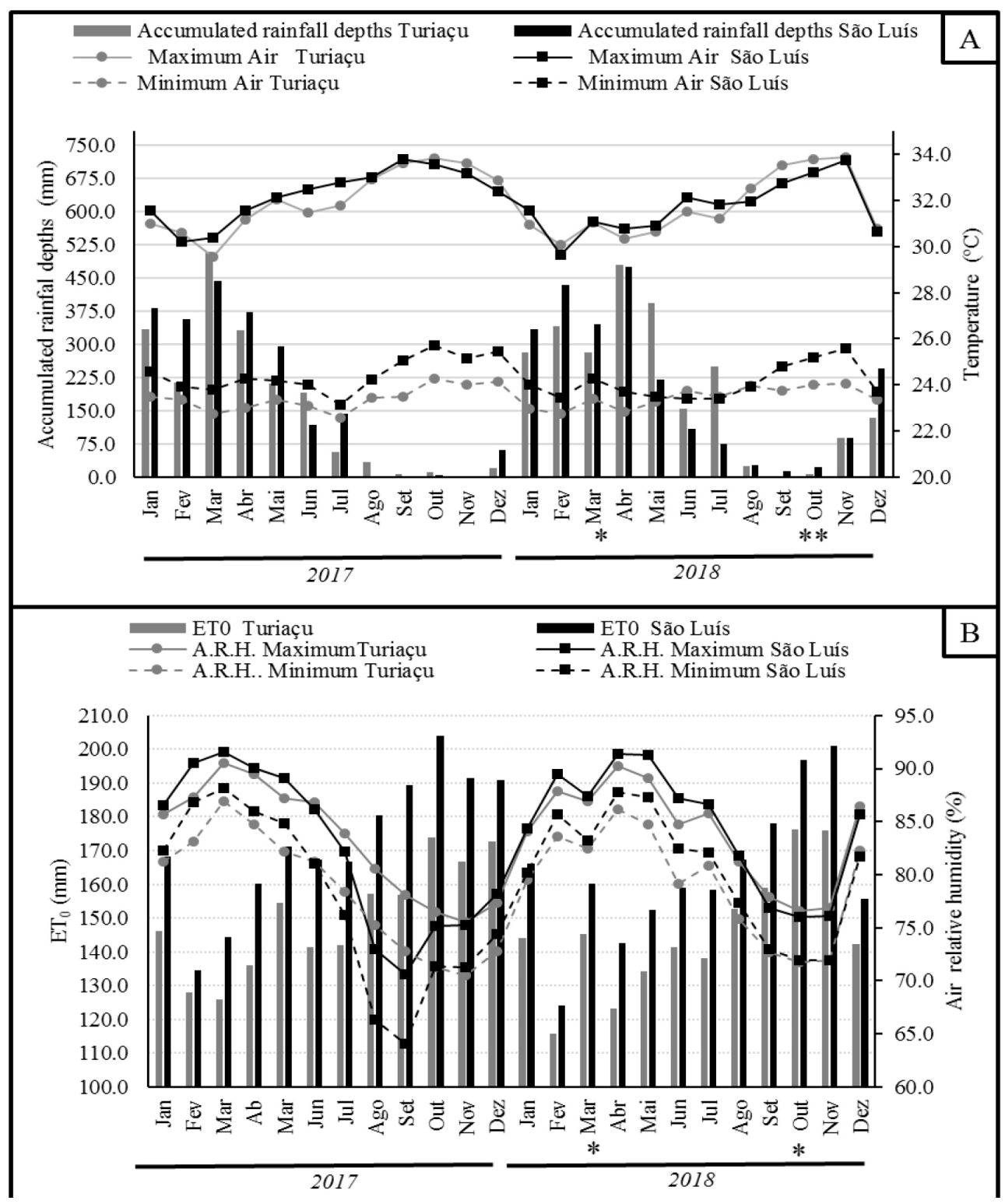

Figure 1. Accumulated rainfall depths, minimum and maximum air temperature (A), reference evapotranspiration (ET0), and minimum and maximum air relative humidity (B) in the municipalities of Turiaçu and São Luís, MA, Brazil, during the experimental period (INMET, 2019). Measurement periods in the vegetative $\left(^{*}\right)$ and propagative $\left({ }^{* *}\right)$ stages. 
The soils of Turiaçu was classified as Plinthic Hapludox and the soil of São Luís as Typic Hapludult (SANTOS et al., 2018). The physical analysis of soil samples of the $0-20 \mathrm{~cm}$ layer showed that the soil texture of both municipalities was sandy loam. Regarding the soil chemical composition, the soils of Turiaçu and São Luís presented, respectively, 13 and $21 \mathrm{~g} \mathrm{dm}^{-3}$ of organic matter, $\mathrm{pH}$ in water of 4.2 and 5.4, 1 and $18 \mathrm{~g} \mathrm{dm}^{-3}$ of $\mathrm{P}$, 9 and $38 \mathrm{mmolc} \mathrm{dm}^{-3}$ of Ca, 9 and 9 mmolc $\mathrm{dm}^{-3}$ of $\mathrm{Mg}$, 2.11 and 2.6 mmolc dm$^{-3}$ of K, 32 and 22 mmolc dm$^{-3}$ of $\mathrm{H}+\mathrm{Al}$, sum of bases of 20.1 and $49.6 \mathrm{mmolc} \mathrm{dm}^{-3}$, cation exchange capacity of 52.1 and $71.6 \mathrm{mmolc} \mathrm{dm}^{-3}$, and base saturation of $39 \%$ and $69.0 \%$.

The experiment was conducted in a randomized block experimental design, with 10 replications, in two growing places. Each block consisted of two plots (mineral fertilization and organic fertilization). The plots contained 33 plants, and the evaluation area consisted of 9 plants (central row). The pineapple was planted in March 2017, using healthy suckers (plantlets with length of $35 \mathrm{~cm}$ ), with spacing of $1.0 \times 0.30 \mathrm{~m}$. The planting under mineral fertilization was carried out in pits, with $10 \mathrm{~g}$ of triple superphosphate and $0.5 \mathrm{~g}$ of boric acid per pit in the base. The planting under organic fertilization was carried out in furrows, using $109 \mathrm{~g}$ of chicken manure, $73 \mathrm{~g}$ of wood ashes, and $58 \mathrm{~g}$ of ground phosphate rock per plant.

Topdressing for plants under mineral fertilization was divided into equal applications at 60, 120, and 180 days after planting (DAP), using $9 \mathrm{~g}$ of urea and $5 \mathrm{~g}$ of potassium chloride per plant, as recommended based on the soil analysis. Topdressing for plants under organic fertilization started at $30 \mathrm{DAP}$, using $55.0 \mathrm{~mL}$ of biofertilizer fertigation per plant, monthly, until 210 DAP. A biofertilizer fertigation $(10 \mathrm{~mL}$ of biofertilizer per liter of water) was applied with the aid of a backpack sprayer.

The biofertilizer used was prepared through an anaerobic fermentation process for 40 days, using the following mixture for 10 liters of biofertilizer: $2.00 \mathrm{~kg}$ of cattle manure, $0.20 \mathrm{~kg}$ of crushed sugarcane, $0.10 \mathrm{~kg}$ of wood ashes, $0.10 \mathrm{~kg}$ of ground phosphate rock, 0.05 $\mathrm{kg}$ of boric acid, $0.04 \mathrm{~kg}$ of zinc sulphate, and $0.20 \mathrm{~L}$ of bovine milk. The nutrient contents in the biofertilizer were determined according to Marrocos et al. (2012) and Tedesco et al. (1995) and presented: $\mathrm{N}=0.37 \mathrm{~g} \mathrm{~L}^{-1}, \mathrm{P}=$ $0.32 \mathrm{~g} \mathrm{~L}^{-1}, \mathrm{~K}=2.69 \mathrm{~g} \mathrm{~L}^{-1}, \mathrm{Ca}=0.25 \mathrm{~g} \mathrm{~L}^{-1}, \mathrm{Na}=0.60 \mathrm{~g}$ $\mathrm{L}^{-1}, \mathrm{Mg}=0.17 \mathrm{~g} \mathrm{~L}^{-1}, \mathrm{Fe}=0.06 \mathrm{~g} \mathrm{~L}^{-1}, \mathrm{Al}=0.016 \mathrm{~g} \mathrm{~L}^{-1}$, $\mathrm{Co}=0.001 \mathrm{~g} \mathrm{~L}^{-1}, \mathrm{Ni}=0.002 \mathrm{~g} \mathrm{~L}^{-1}, \mathrm{~Pb}=0.06 \mathrm{~g} \mathrm{~L}^{-1}, \mathrm{Zn}=$ $0.09 \mathrm{~g} \mathrm{~L}^{-1}, \mathrm{Mo}=0.003 \mathrm{~g} \mathrm{~L}^{-1}$. The plants were subjected to floral induction using solid calcium carbide $\left(\mathrm{CaC}_{2}\right)$ at 1.0 g per plant.
The plants were evaluated at 12 months after planting, when they were at the vegetative stage, for number of leaves and leaf dry weight; width, length, and fresh and dry weights of the D leaf; and stem diameter, length, and dry weight; and at 19 months after planting and after fruit harvest (propagation phase) for number of suckers per plant. Three plants were randomly sampled from the evaluation area of each plot for each evaluation time.

The data were subjected to the Lilliefors normality test and the means of the treatments were compared by the $\mathrm{F}$ test (Anova) in a joint analysis (growing place and fertilization scheme), at 5\% probability level. The Agroestat program was used for the statistical analyses.

The vegetative characteristics of the plants were affected by the growing place and fertilization source. The interaction between the factors were marginally significant for D leaf length. Plants grown in Turiaçu showed better vegetative growth than those grown in São Luís, regardless of the fertilization source. This was probably due to the greater water availability in Turiaçu (precipitation and evapotranspiration) throughout the plant cycle, which allowed a better expression of the genetic potential of the cultivar (Table 1).

Plants grown in Turiaçu under mineral fertilization showed a higher number of leaves (up to $162.5 \%$ higher) and leaf dry weight (up to $55.6 \%$ higher) than those grown in São Luís under organic fertilization. Plants under mineral fertilization showed less leaf chlorosis. These results are due to a possible nutritional imbalance caused by the organic fertilization. Phytotoxicity can affect negatively the plant development, as observed by Cakmak (2005) and Kerbauy (2004); however, leaf analysis to prove this phytotoxicity was not carried out. In addition, the more favorable climate conditions of the municipality of Turiaçu, when compared to São Luís, were probably a determining factor for vegetative growth, because climate variations have considerable impact on vegetative development of pineapple plants (DOREY et al., 2018; WILLIAMS et al., 2017). 
Table 1. Vegetative and reproductive characteristics of Turiaçu pineapple plants grown in Turiaçu and in São Luís, MA, Brazil, under mineral and organic fertilizations.

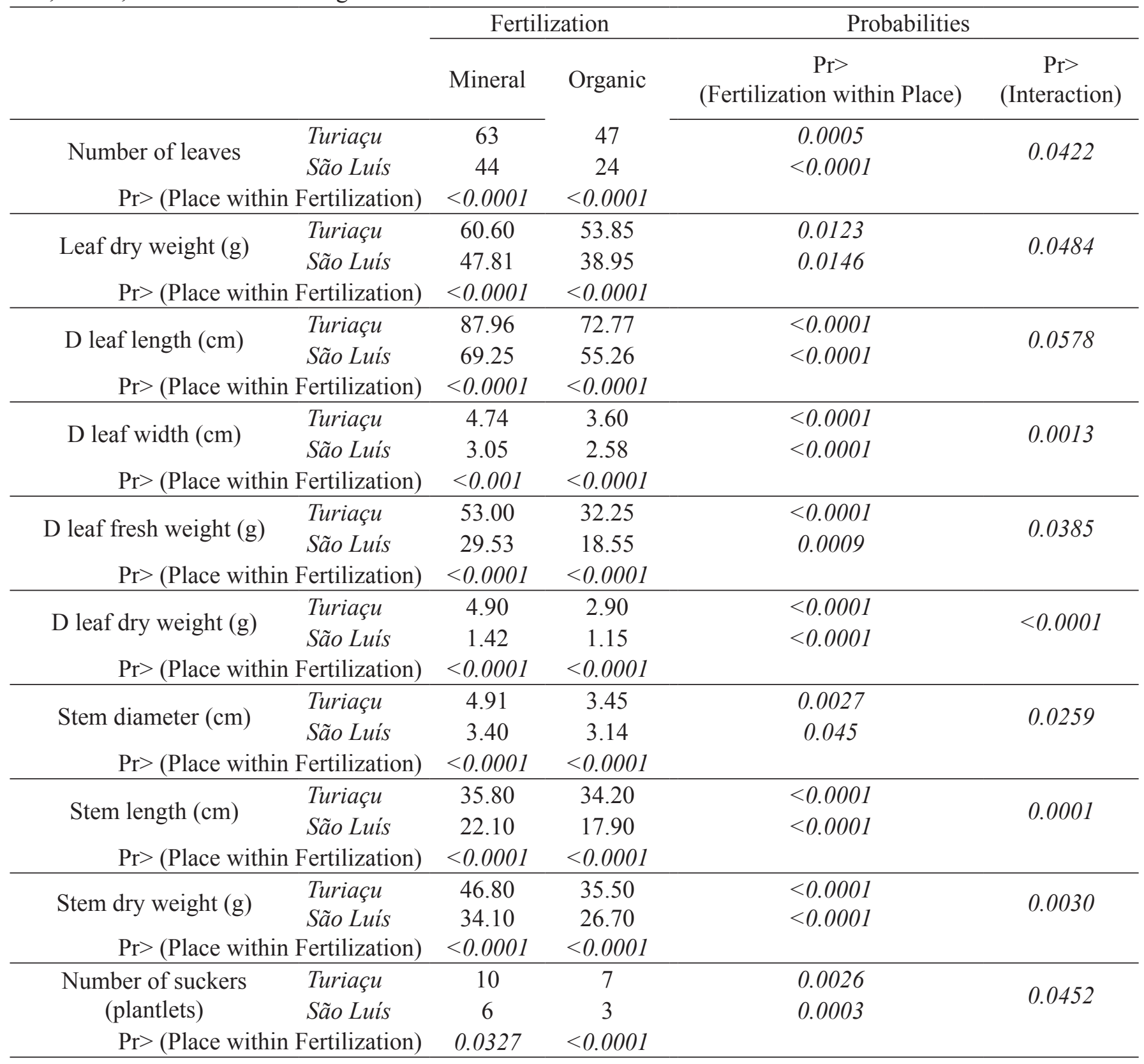

Plants grown in the municipality of Turiaçu presented longer D leaf length (up to $59.2 \%$ longer) than those grown in São Luís. The organic fertilization probably aggravated the plant conditions in the less favorable climate conditions that occurred in São Luís, which resulted in shorter D leaf length. The D leaf lengths found for plants grown under mineral fertilization were longer than those found in the literature for pineapple plants of the cultivars Turiaçu $(84 \mathrm{~cm})$, Perola $(84 \mathrm{~cm})$, and Smooth Cayenne $(67 \mathrm{~cm})$ (ARAUJO et al., 2012; REINHARDT et al., 2002).
The interaction between growing place and fertilization source affected the plant stem growth. Plants grown in Turiaçu had stems with larger diameters (up to $56.4 \%$ larger), longer lengths (up to $100.0 \%$ longer), and greater dry weights (up to $75.3 \%$ greater) than those grown in São Luís. The stem length and diameter of plants of the cultivar Turiaçu grown under mineral fertilization were higher than those found in the literature for pineapple plants of the cultivars Turiaçu $(35.4$ and $2.8 \mathrm{~cm}$, respectively), Perola (34 and $2.8 \mathrm{~cm}$, respectively), and Smooth Cayenne (20 and $2.6 \mathrm{~cm}$, respectively) (ARAUJO et al., 2012; REINHARDT et al., 2002). 
The growing place and fertilization source affected the number of suckers of the cultivar Turiaçu, which is a propagation structure that is usually numerous in plants of this cultivar. Plants grown in Turiaçu had higher number of suckers $(42.8 \%$ higher for mineral, and $100 \%$ higher for organic fertilization) than those grown in São Luís. The organic fertilization affected negatively the number of suckers, both in Turiaçu (54.4\% lower) and in São Luís (57.9\% lower) when compared to the mineral fertilization. In addition to good vegetative characteristics, plants of the cultivar Turiaçu grown in their place of origin and under mineral fertilization had similar production of suckers to those found in other studies evaluating the cultivars Turiaçu (11) and Perola (10), and they presented higher production of suckers than pineapple plants of the cultivar Smooth Cayenne (1) (ARAUJO et al., 2012; CAETANO; VENTURA; BALBINO, 2015). The number of suckers is a desirable characteristic for the formation of new crops, expansion of new cultivars, and improvement of the crop profitability (CAETANO et al., 2013; CUNHA, 2005).

Fertilization with biofertilizer (ammoniacal nitrogen) at 30 days before floral induction, combined with lower water availability and plant development, possibly caused the low plant propagation in São Luís. The organic fertilization may have favored the vegetative growth, which may have contributed to inhibit, delay, or reduce the pineapple sensitivity to floral induction stimuli (CUNHA, 2005).

The climate conditions in Turiaçu, MA, Brazil, favored the vegetative and propagative growth of the pineapple plants of the cultivar Turiaçu, regardless of the fertilization source. Therefore, the water availability favored the development of the plants in their place of origin and was the limiting factor for the expression of the genetic potential of the cultivar.

\section{References}

ARAUJO, J.R.G.; AGUIAR JR, R.A.; CHAVES, A.M.S.; REIS, F.O.; MARTINS, M.R.Turiaçu: a pineapple cultivar traditional and native from Maranhão, Brazil. Revista Brasileira de Fruticultura, Jaboticabal, v.34, n.4, p.1270-1276, 2012.

CAETANO, L.C.S.; VENTURA, J.A.; COSTA, A.F.S. da; GUARCONI, R.C. Effect of fertilization with nitrogen, phosphorus and potassium on growth, yield and fruit quality of pineapple 'Vitoria'. Revista Brasileira de Fruticultura, Jaboticabal, v.35, n.3, p.883-890, 2013.
CAETANO, L.C.S.; VENTURA, J.A.; BALBINO, J.M.D.S. Behavior of pineapple genotypes fusariose resistant compared to susceptible commercial cultivars. Revista Brasileira de Fruticultura, Jaboticabal, v.37, n.2, p.404-409, 2015.

CAKMAK, I. The role of potassium in alleviating detrimental effects of abiotic stresses in plants. Journal of Plant Nutrition and Soil Science, Weinheim, v.168, n. 4, p.521-530, 2005.

CUNHA, G.A.P.da. Applied aspects of pineapple flowering. Bragantia, Campinas, v.64, n.4, p.499-516, 2005.

DOREY, E.; CAMBOUMAC, T.; MICHLES, T.; ROTHE, M.; TIXIER, P. Designing new management sequences for pineapple production using the SIMPIÑA model. Agricultural Systems, Oxford, v.159, p.50-56, 2018.

INMET - Instituto Nacional de Meterologia. Brasília (DF): MAPA, 2019. Disponível em: www.inmet.gov.br/portal/. Acesso em: 1 fev.2019.

KERBAUY, G.B. Fisiologia vegetal. Rio de Janeiro: Editora Guanabara Koogan, 2004.

KUAN, C.S..LEE, T.H.; TSAI, M.H.; TSAI, H.W.; TANG, C.H. A new pineapple cultivar Ananas comosus (L.) Merr.('Tainung no.22'). HortScience, Alexandria, v.53, n.4, p.578-581, 2018.

MARANHÃO. Decreto $\mathbf{n}^{\circ} \mathbf{3 0 . 8 5 1}$ de 12 de junho de 2015. Dispõe sobre a criação do Sistema Estadual de Produção e Abastecimento - SEPAB, e dá outras providências. Maranhão: Procuradoria de Estudos, Documentação e Divulgação Jurídica [2015]. Disponível em: https://www.legisweb.com.br/legislacao/?id=285763.

MARROCOS, S.de T.P.; NOVO JR, J.M.; GRANGEIRO, L.; AMBROSIO, M.M.Q.; CUNHA, A. Microbiological and chemical composition of at different times biofertilizers decomposition. Revista Caatinga, Mossoró, v. 25, n.4, p. 34-43, 2012.

REINHARDT, D.H.; CABRAL, J.R.S.; SOUZA, L.F.S.; SANCHES.N.F.; MATOS, A.P. Pérola and Smooth Cayenne pineapple cultivars in the state of Bahia, Brazil: growth, flowering, pests, diseases, yield and fruit quality aspects. Fruits, Paris, v.57, n.1, p.43-53, 2002. 
REIS, F.O.; ARAUJO, J.; BRAUN, H.; JUNIOR, A.; PEREIRA, A. Fruit quality of a traditional pineapple cultivar (Turiaçu ) compared to the most popular cultivar (Pérola) in Brazil. Australian Journal of Crop Science, Lismore, v.13, n.4, p.546-551, 2019.

SANTOS, H.G. dos; JACOMINE, P.K.T.; NJOS, L.H.C. dos; OLIVEIRA, V.A. de; LUMBRERAS, J.F.; COELHO, M.R.; ALMEIDA, J.A. de; ARAUJO FILHO, J.C. de; OLIVEIRA, J.B. de; CUNHA, T.J.F. Sistema brasileiro de classificação de solos. 5.ed. Brasília: EMBRAPA, 2018. $356 \mathrm{p}$.
TEDESCO, M.J.; GIANELLO, C.; BISSANI, C.A.; BOHNEN, H.; VOLKWEISS, S.J. Análise de solo, plantas e outros materiais. 2.ed. Porto Alegre: Biblioteca Setorial da Faculdade de Agronomia da UFRGS, 1995.

WILLIAMS, P.A.; OLIVIER, C.; CHRISTOPHER, A.; GEORGE, E. Impact of climate variability on pineapple production in Ghana. Agriculture \& Food Security, New York, v.6, n.26, p.1-14, 2017. 